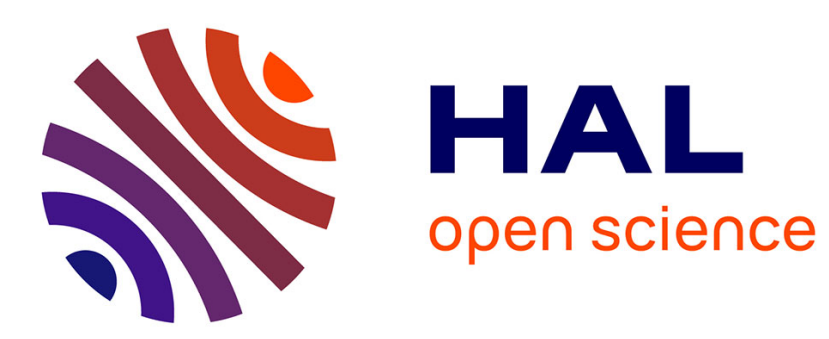

\title{
Undergoer orientation in Movima
}

Katharina Haude

\section{To cite this version:}

Katharina Haude. Undergoer orientation in Movima. Gilles Authier and Katharina Haude. Ergativity, Valency and Voice, Mouton de Gruyter, pp.259-288, 2012. halshs-00692077

\section{HAL Id: halshs-00692077 https://shs.hal.science/halshs-00692077}

Submitted on 27 Apr 2012

HAL is a multi-disciplinary open access archive for the deposit and dissemination of scientific research documents, whether they are published or not. The documents may come from teaching and research institutions in France or abroad, or from public or private research centers.
L'archive ouverte pluridisciplinaire HAL, est destinée au dépôt et à la diffusion de documents scientifiques de niveau recherche, publiés ou non, émanant des établissements d'enseignement et de recherche français ou étrangers, des laboratoires publics ou privés. 


\title{
Undergoer orientation in Movima [final draft]
}

\author{
Katharina Haude
}

\section{Introduction ${ }^{1}$}

This article explores the system of verbal voice morphemes in Movima (unclassified, Amazonian Bolivia) and seeks to explain why most transitive main clauses in Movima pattern ergatively. Movima has two basic transitive constructions, direct and inverse, overtly distinguished by verbal morphemes. In main clauses, to which the discussion in this paper is restricted, the direct construction patterns ergatively and the inverse construction patterns accusatively. In terms of statistical frequency, the large majority of transitive main clauses in texts is direct, i.e. ergative.

The direct and inverse markers, which are employed according to the relative position of the participants on a referential hierarchy (Haude 2009, 2010), belong to a paradigm of verbal morphemes (reflexive/reciprocal, resultative, agentive, middle) that indicate the transitivity of the verb and the participant (macro)role - actor or undergoer - of its subject. They can only be applied productively to one class of verbal bases, which in their majority denote two-participant events. When a verb of this class occurs without an overt voice marker, it is syntactically intransitive and denotes a state, which means that its subject has the undergoer (theme) role. Furthermore, resultative verbs, which also take an undergoer (patient) as subject, can be identified as being morphologically the least marked of all voice-marked verbs. Unmarked verbs of this class can therefore be considered undergoer oriented. The proposal of this paper is to consider the direct voice marker as a morpheme that derives a transitive verb by simply adding a syntactic position for an actor argument, leaving the undergoer orientation of the verb untouched and thus creating an ergative structure. The inverse marker, under this view, is a secondary derivation, reversing the participant roles of the arguments of a transitive clause according to the referential hierarchy and discourse status.

The paper is structured as follows. Section 2 presents the syntactic properties of transitive and intransitive predicates and their arguments: Section 2.1 illustrates the distinction between transitive and intransitive predicates, the encoding of the arguments of transitive clauses and the function of 


\section{Katharina Haude}

direct and inverse marking; Section 2.2 demonstrates that the argument that represents the undergoer in a direct transitive clause has the same formal and behavioural properties as the $\mathrm{S}$ argument of the intransitive clause, leading to an ergative pattern, whose status is further discussed in 2.3. Section 3 describes the verbal voice morphemes. Section 4 gives an overview of the verbal bases that can (4.1) and cannot (4.2) participate in the voice system, showing that the members of the first class typically denote twoparticipant events and the members of the second class one-participant events. Section 5 argues that semantically bivalent verbs are undergoeroriented and that this may contribute to the default ergativity of transitive clauses. The conclusions are drawn in Section 6.

\section{Clause structure and ergativity}

2.1. Transitive and intransitive clauses

There are two classes of predicates in Movima: transitive and intransitive. They can be identified by the ability to be combined with two overt argument expressions. A transitive predicate can take two overt argument expressions, as in (1).

$$
\begin{array}{lll}
\text { tikoy-na=us } \quad \text { os } & \text { rulrul } \\
\text { kill-DR=3M.AB } & \text { ART.N.PST } & \text { jaguar } \\
\text { 'He killed the jaguar.' } &
\end{array}
$$

An intransitive clause may only contain one argument expression; any other event participant can only be expressed as an adjunct, marked by the oblique prefix. Example (2) shows that the verb kaykay 'eat', despite its meaning, is intransitive: the eaten object ('those nuts') can only be expressed as an adjunct.

$$
\begin{aligned}
& \text { kay kay is karak ni-kis } \quad \text { ney cho choK-kwa } \\
& \text { MD eat ART.PL macaw OBL-ART.PL.AB DEF RED nut-ABS } \\
& \text { 'The macaws eat those nuts.' }
\end{aligned}
$$

The two core arguments in a transitive clause, identified by the fact that they do not carry the oblique marker, are distinguished from each other by 
their constituency properties: one is expressed by a constituent internal to the predicate phrase, the other by a constituent external to it, as illustrated in (3). These properties are reflected by the following features: the internal nominal constituent (=us in (1)) is inseparably attached to the predicate by "internal cliticization" (causing stress shift; marked as $=$ ) and is obligatorily expressed; the external nominal constituent (os rulrul in (1)) is attached through "external cliticization" (when bound pronoun; leading to resyllabification but no stress shift; marked as -- ) or not phonologically attached at all (when free pronoun or NP), other elements can occur between it and the predicate phrase, it is not obligatorily expressed, and it is easily replaced by a free pronoun in clause-initial position (for more details see Haude 2006, 2010).

$$
\text { [PRED=ARG] [ARG] }
$$

Whether an argument is represented by the internal or the external constituent depends primarily on its referential properties (see Haude 2009, 2010). The expression of speech-acts participants (except second person plural; see Haude forthcoming) is restricted to the internal position. When two third persons interact, the more topical one is represented by the internal constituent; typically, the internal constituent is a pronoun and the external one a noun phrase, as in the above examples.

Constituency alone does thus not indicate the participant roles (actor or undergoer) of the arguments. ${ }^{2}$ These are indicated by verbal morphemes. When the internal constituent is the actor and the external constituent the undergoer, the verb is marked as direct; when the situation is reversed, the verb is marked as inverse, as shown in (4).

$$
\begin{array}{llll}
\text { tinok-poj-kay- } a=\text { us } & \text { os } & \begin{array}{l}
\text { merek } \\
\text { rulrul }
\end{array} & \begin{array}{l}
\text { big } \\
\text { scare-CAUS-INV-EP=3M.AB } \\
\text { 'The big jaguar scared him.' }
\end{array}
\end{array}
$$

The fact that the arguments are primarily encoded according to their referential properties and not according to participant roles, makes it difficult to provide them with uncontroversial labels. Following Bickel (2010), I use terms that are based on the referential properties of the arguments, labelling the argument internal to the predicate phrase (high-ranking) as "proximate" and to the argument external to the predicate phrase as "obviative" (short PROX and OBV, respectively). As we will see in the following section, the OBV argument has the syntactically privileged status. 


\subsection{The syntactic subject}

The single argument of an intransitive clause (S) has the same morphosyntactic properties as OBV of a transitive clause: it is phonologically independent, cliticized only when bound pronoun, not obligatorily expressed, and can easily replaced by a free pronoun. Moreover, on the syntactic level, OBV and S have access to syntactic operations to which PROX does not have access.

The clearest case is relativization. A relative clause is introduced by the particle $d i$ ' following the relativized noun phrase, which is not expressed again in the relative clause. Example (5) shows an intransitive relative clause.

$$
\begin{array}{lllll}
\text { kinos ney ay'ku [di' jayna } & \text { kayni] } \\
\text { ART.F.AB here aunt REL } & \text { DSC } & \text { die } \\
\text { 'That aunt of mine who has died already.' }
\end{array}
$$

Examples (6) and (7) illustrate the relativization of OBV. In (6), the relativized argument is the undergoer, therefore the predicate of the relative clause is marked as direct; in (7), the relativized argument is the actor, therefore the predicate is marked as inverse.

$$
\begin{array}{lll}
\text { kinos } \quad \text { alwaj-a=us [di' } & \text { naye-Ke-na=us }] \\
\text { ART.F.AB } & \text { spouse-EP=3M.ABREL } & \text { marry-CO-DR=3M.AB } \\
\text { 'his wife, whom he had married' } &
\end{array}
$$

$$
\begin{aligned}
& \text { is } \quad \text { pa:ko } \quad[d i \text { ' lap-kay-a=as] } \\
& \text { ART.PL dog } \\
& \text { '(the) dogs who bit it [the jaguar]' }
\end{aligned}
$$

In order to relativize the participant represented as PROX, a detransitivizing voice operation has to be applied. Here, the predicate is preceded by a particle kwey (or kaw), the clause is intransitive with the original PROX as its single argument; the original OBV is (optionally) expressed as an adjunct, marked by the oblique prefix. This process is generally found with direct predicates, where it has an antipassive effect. It is illustrated in (8)b, which contrasts with (8)a, the transitive construction. 

a. jayna rey way-na=is kinos rey sonsa DSC MOD lift-DR=3PL.AB ART.F.AB MOD silly
'Then they had already taken up that silly (woman).'
b. is juyeni [di' jayna kwey way-na n-i'ne] ART.PL person REL DSC DETR lift-DR OBL-PRO.3F 'the people who had taken her up'

While the syntactically privileged status of OBV as opposed to PROX in relative clauses is clear, there is no evidence of any construction to which PROX, but not OBV, has access (Haude 2009). Therefore, in the remainder of this paper and in line with other contributions in this volume (MonodBecquelin and Becquey; Queixalós), I use the term "subject" to refer to the grammatical relation encompassing $\{\mathrm{OBV}, \mathrm{S}\}$. While based here entirely on syntactic grounds, the term seems suited best for making the patterns in Movima comparable to voice patterns in other languages, since discussions of voice phenomena generally make use of the subject notion (see e.g. Mithun 1994; Kulikov 2010).

\subsection{Ergativity}

Given that OBV aligns with $S$, it is obvious that when the participant roles of the arguments are considered, the direct/inverse alternation results in two basic transitive clause types, one with an ergative and the other with an accusative pattern. In the direct construction, OBV represents the undergoer, and in the inverse construction, OBV represents the actor.

With respect to formal marking, the split is entirely parallel: whenever PROX is the actor and OBV the undergoer, the pattern is ergative; whenever OBV is the actor and PROX the undergoer, the pattern is accusative. In both cases, the predicate is overtly morphologically marked. However, with respect to discourse frequency and pragmatics, there is evidence that direct/ergative construction is the default for transitive clauses (see also Haude 2010).

First of all, the direct construction is statistically more frequent, occurring in about $80 \%$ of the transitive clauses with two third-person arguments. This is not surprising, since a high-ranking actor and a low-ranking undergoer represent the typical participant constellation in a twoparticipant event (cf. DeLancey 1981; Givón 1994; Croft 2003). 


\section{Katharina Haude}

Evidence for the pragmatically unmarked character of the direct construction is also apparent from the fact that this construction is occasionally found in opposition to the referential hierarchy, while this is never the case with the inverse construction. When two third-person arguments are represented by pronouns or both by full noun phrases, reflecting an equal discourse status, then automatically the direct construction is used. This is the case in elicitation, and it is illustrated by the text example in (9), where both arguments are encoded as noun phrases: even though the actor is an animal and the undergoer a human, the construction is direct and the actor is represented as PROX. The text corpus contains no example of the reversed case, i.e. the inverse construction with the referentially lowerranking participant represented as PROX. In elicitation, the inverse construction in such a context is accepted, but never proposed spontaneously.

$$
\begin{array}{llrrr}
\text { jayna } & \text { lap-na=as } & \text { mimi:di } & \text { us } & \text { majni! } \\
\text { DSC } & \text { bite-DR=ART.N } & \text { snake } & \text { ART.M } & \text { my_offspring }
\end{array}
$$

'Now the/a snake bit my son!'

The inverse construction, furthermore, has only limited access to the detransitivising voice operation with kwey. A kwey-construction with an inverse predicate occurs nowhere in the text corpus. In elicitation, certain examples with a kwey-construction and an inverse predicate, like the one in (10)b, tend to be rejected; the exact conditions of this still need to be investigated, but in any case, the limited acceptability of such examples means that the use of an inverse predicate in the kwey-constructon is problematic.

$$
\begin{aligned}
& \text { a. inKa kwey dul-na n-isne } \\
& \text { PRO.1SG DETR visit-DR OBL-PRO.3F.AB } \\
& \text { 'It was me who visited her.' } \\
& \text { b.? inKa kwey dul-kay n-isne } \\
& \text { PRO.1SG DETR visit-DR OBL-PRO.3F.AB } \\
& \text { ('It was me who was visited by her.') }
\end{aligned}
$$

I conclude that while there is no difference in morphological markedness between the inverse and the direct construction, the direct construction is the default transitive construction, used when two third-person participants are ranked equally in terms of discourse status. The inverse construction, in contrast, is restricted to the situation in which the undergoer outranks the actor with regard to person, animacy and discourse prominence. Further- 
more, the detransitivising operation with kwey is largely restricted to the direct construction. The default transitive affirmative main clause in Movima, therefore, has an ergative pattern.

\section{Voice markers}

The direct and inverse markers belong to a paradigm of verbal morphemes that indicate the transitivity of a verb and the participant role(s) of the core argument(s). They are listed in Table 1.

Table 1. Movima voice markers

\begin{tabular}{llll}
\hline transitivity & marker & meaning & subject role \\
\hline transitive & $-n a /-a-$ & direct & $\mathrm{Ug}$ \\
& $-k a y$ & inverse & $\mathrm{Ac}$ \\
\hline intransitive & $-c h e K$ & reflexive/reciprocal & $\mathrm{Act}+\mathrm{Ug}$ \\
& $-i$ & resultative & $\mathrm{Ug}$ \\
& $-e K e$ & agentive & $\mathrm{Act}$ \\
& $\langle R E D \sim>$ & middle & $\mathrm{Act}+\mathrm{Ug}$ \\
\hline
\end{tabular}

A first illustration of the effect of the voice markers is provided in (11) with the transitive root jat- 'hit'. (The reduplicative middle marker is not illustrated here because it is not fully productive and does not occur with this root.)

$$
\begin{array}{lll}
\text { direct: } & \text { jat-na= }= & \text { 'I hit X' } \\
\text { inverse: } & \text { jat-kay=Ø } & \text { 'X hits me' } \\
\text { reflexive: } & \text { jat-cheK } & \text { 'X hit(s) themselves/each other' } \\
\text { resultative: } & \text { jat-'i } & \text { 'X has been hit.' } \\
\text { agentive: } & \text { jat-eKe } & \text { 'X hits (continuously/habitually)' }
\end{array}
$$

These morphemes can be adequately analysed as voice markers because of their property to indicate the transitivity of a verb and the participant role of the verb's subject, which are characteristics of voice marking as defined cross-linguistically. They also serve to present an event from varying perspectives (see Shibatani 2006). They do not seem, however, to be employed for syntactic purposes (this is the role of the particle kwey, see 2.2 above), and none of them derives an intransitive verb from a transitive one, a feature present in many traditional definitions of voice (see Kulikov 2010). 


\section{Katharina Haude}

They have aspectual (Aktionsart) and sometimes modal connotations. In the following discussion, however, I will focus on their voice-marking property, i.e. the way in which they assign arguments to the verb.

\subsection{Transitive voice markers: direct and inverse}

As was shown in 2.1 above, transitive predicates contain either the direct or the inverse morpheme. The direct morpheme has two allomorphs: basefinal $-n a$ and base-internal $-a$-, which are both illustrated in (12). The baseinternal allomorph $-a$ - is applied like an infix: it is inserted in morphologically complex verbal bases immediately after the root, as in (12)b, provided that the root be a single closed syllable not followed by an aspectual suffix (e.g. - $k a$ 'MLT'). Being based on prosodic properties of the base, the insertion of the direct marker $-a$ - can create non-linear morphological patterns. For example, in (12)b the direct marker precedes the causative suffix $(-p o j)$ in linear order, but it is applied at a later stage of the verbal derivational process, after the causative suffix has derived the bivalent base.

$$
\begin{aligned}
& \text { a. lat-na=is kis ko'o, } \\
& \text { chop-DR=3PL.AB ART.PL.AB tree } \\
& \text { b. tok-a-poj-a=is ba:ra kis ko'o } \\
& \text { fall-DR-CAUS-EP=3PL.AB all ART.PL.AB tree } \\
& \text { 'They chop down the trees, they fell all the trees.' }
\end{aligned}
$$

In all other environments, the suffix -na is applied, as illustrated in (12)a with a simple root and in (13) with a complex base with an open-syllable root.

$$
\begin{array}{llll}
\text { jayna } & \text { chi-poj-na=is } & \text { us } & \text { majni } \\
\text { DSC } & \text { go_out-CAUS-DR=3PL.AB } & \text { ART.M } & \text { my_offspring } \\
\text { 'They took my child out (of my body).' } &
\end{array}
$$

Some bivalent bases seem to be historically complex, since they take the direct marker $-a$ - instead of $-n a$, but synchronically, their components cannot be properly identified. An example is given in (14), with the verb base $k a y K e$ 'give', whose final syllable is most probably the applicative suffix -Ke, but whose first syllable kay (homophonous with the root kay- 'eat') cannot be identified as a root on the synchronic level. 
(14)

$$
\begin{array}{lcr}
k a y<a:>K e=\emptyset & n-i \text { 'ko } & \text { jayna } \\
\text { give }<\mathrm{DR}>=1 \mathrm{SG} & \text { OBL-PRO.3PL } & \text { DSC } \\
\text { 'I'll give it (the money) to you.' }
\end{array}
$$

The inverse marker invariably consists of the suffix -kay (presumably unrelated to the verb root 'eat' or 'give') independently of whether the verb takes the suffix -na ((15), cf. (13)) or its allomorph - $a$ - ((16), cf. (14)) as direct marker. Since its final phoneme /j/ $(y)$ is a consonant, the epenthetic vowel $-a$ is added before an internal enclitic (as in (4) and (7) above; see Haude 2006: 98-99). As was shown in 2.1, the inverse suffix derives a transitive predicate whose subject is the actor.

$$
\begin{array}{lllll}
\text { chi-poj-kay }=\varnothing & \text { isnos } & \text { kayni } & \text { di' } & \text { nonok } \\
\text { go_out-CAUS-INV=1SG } & \text { ART.F.PST } & \text { die } & \text { REL } & \text { my_grandmother }
\end{array}
$$
'My late grandmother took me out (of school).'

$$
\begin{array}{lll}
\text { kayKe:-kay }=\emptyset \text { - }- \text { isne } & n \text {-is } & \text { narasa-mes- } a=\text { sne } \\
\text { give-INV=1SG--3F.AB } & \text { OBL-ART.PL } & \text { orange-CL.fat-EP=3F.AB } \\
\text { 'She gave me her orange oil.' } &
\end{array}
$$

In the third-person domain, the application of the direct and inverse markers depends very much on the relative topicality of the arguments, since the topical argument is generally represented as PROX. Here, the inverse assumes the function of a voice marker (cf. Gildea 1994), as is reflected by the fact that it can generally be translated by a passive, as in (17).

$$
\begin{array}{lll}
\text { us } & \text { bi:jaw, } & \text { jiw- } a-\text { Ke-kay- } a=u s \\
\text { ART.M old } & \text { come-DR-CO-INV-EP=3M.AB } \\
\text { us } & \text { kayni } & \text { di } \text { ' Koyimbra } \\
\text { ART.M die } & \text { REL proper_name } \\
\text { 'The old (man), he was brought by the late Coimbra.' }
\end{array}
$$

\subsection{Intransitive voice markers}

The intransitive voice markers create predicates that can only take one overt core argument expression. 


\subsection{1. -cheK reflexive/reciprocal}

The reflexive/reciprocal suffix - che $K$ is the most productive intransitive voice marker, combinable with any verb that can be marked as direct or inverse. It creates a verb whose subject represents one or more participant(s) that simultaneously carry out and undergo an action. The interpretation as either reflexive (18) or reciprocal (19) depends on the context.

$$
\begin{array}{llcc}
\text { didi' } & \text { tikoy-che } K & n \text {-os } & \text { kachi:ra } \\
\text { FRUST } & \text { killed-R/R } & \text { OBL-ART.N.PST } & \text { knife } \\
\text { '(He) wanted to kill himself with a knife.' }
\end{array}
$$

$$
\begin{aligned}
& \text { ban jayna don-che } \boldsymbol{K}-\text {-is } \\
& \text { but DSC dislike-R/R--3PL.AB } \\
& \text { '... but they already disliked each other.' }
\end{aligned}
$$

[HRR tx 191]

In 4.2 below it will be shown that when attached to so-called monovalent bases, this suffix is deprived of its reflexive/reciprocal meaning and only marks an activity.

\subsection{2. -'i resultative}

The suffix - ' $i$ marks an intransitive verb denoting a resultative state, i.e. a verb expressing "both a state and the preceding action it has resulted from" (Nedjalkov and Jaxontov 1988: 6). The subject of the resultative verb represents the undergoer.

$$
\begin{aligned}
& \text { ben-'i is chorimpa=sne } \\
& \text { paint-RES ART.PL fingernail=3F.AB } \\
& \text { 'Her fingernails were painted.' }
\end{aligned}
$$

$$
\begin{aligned}
& \text { bo rey os bet'i vus-'i-as } \\
& \text { REAS MOD ART.N.PST grassland carbonize-RES--3N.AB } \\
& \text { che kaw-ra is ve'e:-vus } \\
& \text { and much-BE.NTR ART.PL fire-CL.dust }
\end{aligned}
$$


'... because the grassland, it had been burnt [by the farmers] and there were lots of ashes.'

Depending on the context, the suffix - ' $i$ can also express a deontic modality ('X has to be done'); it is used in instructions and procedural texts:

$$
\begin{aligned}
& \text { che jayna n-as ba:-paj-uk-wa=n jayna } \\
& \text { and DSC OBL-ART.N finish-split-NMZ=2 DSC } \\
& \text { il-'i-is, tamol-'i-is daya'a } \\
& \text { spread-RES--3PL.AB expand-RES--3PL.AB DUR.NSTD }
\end{aligned}
$$

'And when you finish splitting (the straws), then they are/have to be spread out, they are/have to be extended.'

$$
\begin{aligned}
& \text { raK-'i is pe:ra, il-'i, jayaw-' } \boldsymbol{i} \text {, } \\
& \text { pull_out-RES ART.PL reed spread-RES nice-RES } \\
& \text { werel-niche pil-'i no-kos do:nojbet ney }
\end{aligned}
$$

dry-PRC and rolled_up-RES OBL-ART.N.AB cloth here 'The reed is pulled out, (it) is spread, (it) is made nice, (it) dries and is rolled up with a cloth like this...'

In traditional voice terminology, the resultative comes closest to a passive (cf. Comrie 1981), since it creates an intransitive predicate whose subject is the undergoer. However, in difference to a canonical passive (cf. e.g. Siewierska 1984; Shibatani 1985; Dixon and Aikhenvald 2000; Kazenin 2001; Keenan and Dryer 2007), there is no sign of derivation from an unmarked transitive, active verb: the base to which the resultative suffix is attached is stative rather than active (see Section 5 below), and transitive predicates are overtly morphologically derived. In fact, instead of being a derived form, the resultative even seems to be the morphologically leastmarked form of a bivalent verb root (see Section 5 below).

The agent is not expressed in a clause with a resultative verb; the few cases in the corpus where an oblique phrase in a resultative clause might be interpretable as an agent are cases like (24), where an oblique phrase (nis alamre) denotes the entity by which the state was caused. In general, also in resultative clauses obliques encode peripheral roles such as locations, times or instruments, as in (23) above (nokos do:nojbet) or (25).

$$
\begin{array}{lcccc}
\text { biK-'i } & \text { is } & \text { dinoj-a='ne } & \boldsymbol{n} \text { - } i \text { s } & \text { alamre } \\
\text { scratch-RES } & \text { ART.PL } & \text { thigh-EP=3F } & \text { OBL-ART.PL wire }
\end{array}
$$


'Her legs were scratched from the wire.'

$$
\begin{array}{llll}
\text { pay'-'i } \quad \boldsymbol{n} \text {-is } \quad \text { bubutkwa } & \text { os ro:ya } \\
\text { smear-RES } & \text { OBL-ART.PL mud } & \text { ART.N.PST house } \\
\text { 'The house was plastered with mud.' } &
\end{array}
$$

\subsection{3. - eKe agentive}

The agentive marker $-e K e$ derives an intransitive verb whose subject is the actor, as illustrated in (26). In this way, the agentive suffix resembles an antipassive, and like many antipassives (see Cooreman 1994), it indicates a durative or habitual action. However, in the same way as the resultative marker, the agentive marker does not derive an intransitive from a transitive verb, which belongs to the definition of a typical antipassive (see Dixon 1994: 146).

$$
\begin{aligned}
& \text { jayna jo'yaj, } \quad \text { sal-e:Ke--y'Ki} \\
& \text { DSC arrive search_for-AGT--1PL } \\
& \text { 'Then (we) arrived, we searched.' }
\end{aligned}
$$

Verbs containing the suffix $-e K e$ are often combined with an obliquemarked noun phrase denoting the patient, as in (27) and (28). However, oblique phrases can encode many relations, which can only be inferred from the context. For example, in (27) and (28), the oblique NP is identified by the context as a patient, while in (29), the context identifies it as a location.

$$
\begin{array}{llcc}
\text { jayna } & \text { jot-e: } \text { Ke } & n \text {-is } & \text { chekwesKa } \\
\text { DSC } & \text { gather-AGT } & \text { OBL-ART.PL } & \text { tarumá } \\
\text { 'Then (I) gathered tarumá fruits.' } & \text { [JAO tx 026] }
\end{array}
$$

$$
\begin{aligned}
& \text { raK-pit-e:Ke } \quad \boldsymbol{n} \text {-is } \quad \text { kade:na } \\
& \text { tear-BE.half-AGT } \quad \text { OBL-ART.PL chain } \\
& \text { '[The wild cat] tore the chain [and escaped].' }
\end{aligned}
$$

$$
\begin{array}{lll}
\text { sal-e: } K \boldsymbol{e} \text {--us } & \boldsymbol{n} \text {-is } & \text { wolsiko=us } \\
\text { search_for-AGT--3M.AB } & \text { OBL-ART.PL pocket=3M.AB } \\
\text { 'He searched in his pockets [for bullets].' }
\end{array}
$$




\subsubsection{Middle reduplication}

The middle marker consists of a full reduplication of monosyllabic and a partial reduplication of disyllabic roots (see Haude 2006: 345ff.). I call it "middle" because reduplicated verbs generally denote events that affect the subject participant in some way. Consider the difference between the direct-marked verb in (30) with the middle verb in (31):

$$
\begin{array}{llcc}
\text { iK } & \text { Kap-na }=\varnothing & \text { is } & \text { ona:cho } \\
\text { 1SG } & \text { bathe-DR=1SG } & \text { ART.PL } & \text { my_grandchild }
\end{array}
$$

'I bathe my grandchildren.'

$$
\begin{array}{ll}
\text { jayna } & \text { Kap Kap--i'ne } \\
\text { DSC } & \text { MD bathe--3F }
\end{array}
$$

'Then she bathed.'

The same difference is illustrated with a longer verb root, chumay-, whose middle form is created by reduplication of the penultimate syllable. Example (32) illustrates the direct, (33) the middle form of the verb.

$$
\begin{array}{llll}
\text { chumay-na=n} & \text { kos } & \text { bo } \sim b o j-a=k o s & k o^{\prime} \\
\text { smoke-DR=2 } & \text { ART.N.AB RED base-EP=ART.N.AB tree }
\end{array}
$$

'You smoke out the trunk of the tree [for collecting honey].'

$$
\begin{array}{lll}
k o s \quad d a & v e ' & \text { chu<ma: > may } \\
\text { ART.N.AB DUR.NSTD fire } & \text { smoke }<\mathrm{MD} \sim> \\
\text { 'The fire is smoking.' }
\end{array}
$$

The middle marker is not very productive on the so-called "bivalent" bases (4.1); in contrast, it frequently occurs with "monovalent" bases, from which it derives activity verbs (see 4.2). 


\section{Katharina Haude}

\section{Types of verb bases}

Two types of verbal bases can be distinguished in Movima: bases that participate fully in the voice system and bases that do not. The defining criterion for their distinction is a formal one: on verbs of the first class, the suffixation of - $n a$ derives a transitive predicate in the way described in 2.1, whereas on verbs of the second class, the suffixation of -na derives a locational noun. The two classes are furthermore characterized semantically: bases of the first class denote two-participant events, while most bases of the second class denote one-participant events; bases of the first class, when unmarked for voice, are stative predicates, while unmarked bases of the second class typically denote activities. The two classes are described in the following sections.

\subsection{Bivalent bases}

The bases that participate fully in the voice system typically denote events that imply at least two participants, including prototypical transitive events (Hopper and Thompson 1980) like 'hit' or 'kill'. Therefore, I refer to the bases of this class as "bivalent". ${ }^{3}$ Bivalent bases can be either simple (i.e. roots) or complex; most complex bases can occur independently, while roots cannot.

Examples of bivalent verb roots, of which there are about 150 (see Haude 2006: 555ff.), are listed in (34).

$$
\begin{array}{ll}
\text { jat- } & \text { 'hit' } \\
\text { Kek- } & \text { 'kick' } \\
\text { lap- } & \text { 'bite' } \\
\text { sal- } & \text { 'search for' } \\
\text { yey- } & \text { 'want' } \\
\text { ju:- } & \text { 'scold' } \\
\text { tikoy- } & \text { 'kill' } \\
\text { ela- } & \text { 'leave behind' } \\
\text { ji:sa- } & \text { 'make' }
\end{array}
$$

Verb roots cannot occur independently; they must be combined with another morpheme, e.g. a voice marker, as illustrated in (34) above. In Section 5 below I will argue that the resultative voice, marked by - ' $i$, can be considered the least marked form of bivalent roots. 
Bivalent bases can also be morphologically complex, i.e. can consist of a root plus a derivational morpheme (like causative or applicative) or a modifying incorporated element (see Haude 2006: Ch. 9). Consider the base jam-Ke in (35), which combines with most voice markers:

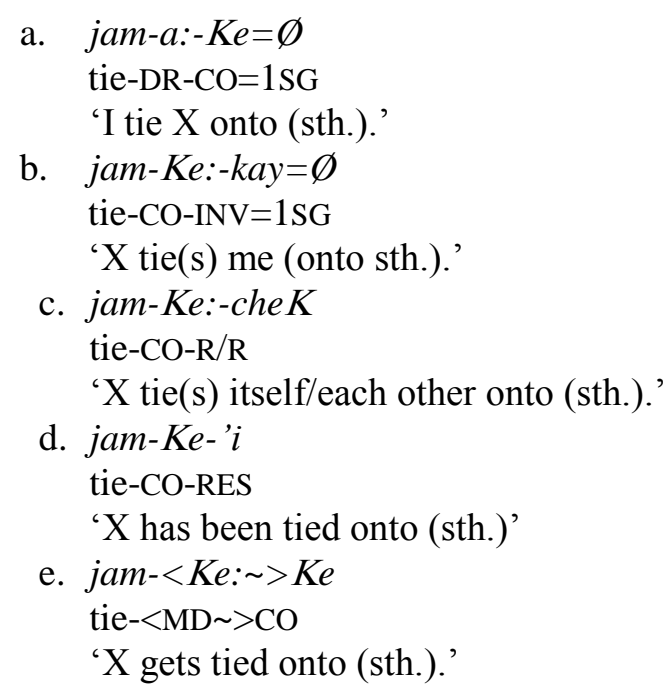

Unlike roots, most complex bivalent bases can occur independently, in which case they denote a state. Example (36), illustrating the base jamKe from (35) above, is from elicitation; (37) illustrates the occurrence of an unmarked bivalent bases in texts (see Section 5 below for more examples):

$$
\text { jam-Ke--i n-is wa wa-n-kwa }
$$
tie-CO--3N OBL-ART.PL RED liana-LN-ABS 'They are tied onto (sth.) with a liana.'

$$
\begin{array}{lccc}
\text { am-poj } & \text { is } & \text { Santo rey jayna } \\
\text { enter-CAUS ART.PL Saint MOD DSC } & \text { Sad } \\
\text { 'The Saints had already been put in again.' }
\end{array}
$$

\subsection{Monovalent bases}

The so-called monovalent bases, in contrast, cannot be combined with the full range of voice markers. This group, though semantically less consistent 
than the one described above, includes elements referring to oneparticipant events like 'sleep' or 'stand', which is why I refer to them as monovalent. Examples of monovalent roots are listed in (38) (see Haude 2006: 340ff.).

$$
\begin{array}{ll}
\text { joy- } & \text { 'go' } \\
\text { en- } & \text { 'stand' } \\
\text { as- } & \text { 'sit' } \\
\text { de:- } & \text { 'lie' } \\
\text { josi- } & \text { 'laugh' } \\
\text { chi- } & \text { 'go out' } \\
\text { jiwa- } & \text { 'come' } \\
\text { kay- } & \text { 'eat' } \\
\text { dejal- } & \text { 'cook' } \\
\text { Kokot- } & \text { 'boil' }
\end{array}
$$

The formal diagnostic for identifying a monovalent base is the effect of the suffix -na. With bivalent bases, the addition of this suffix (or its allomorph $-a$ - on certain complex bases) creates a direct transitive predicate, while on monovalent bases, the suffixation of -na creates a locational noun; the difference is illustrated in (39) (bivalent) and (40) (monovalent).

$$
\begin{aligned}
& \text { jat-na=Ø } \\
& \text { hit-DR=1SG } \\
& \text { 'I hit (you/him/her/it/them) }
\end{aligned}
$$

$$
\begin{aligned}
& k a y-n a=\emptyset \\
& \text { eat-LOC=1SG } \\
& \text { 'the place where I eat' }
\end{aligned}
$$

The derived locational nouns can be identified as nouns because, when functioning as predicates, their subject can only be expressed by a clauseinitial free pronoun and not by an externally cliticized pronoun, as shown in (41)a and (41)b, respectively. They share this syntactic limitation with possessed nominal predicates (see Haude 2010).

$$
\begin{aligned}
& \text { a. bo a'ko as-na=Ø } \\
& \text { REAS PRO sit-LOC=1SG } \\
& \text { 'because it is my house' }
\end{aligned}
$$


b. *bo $a s-n a=\emptyset--a$

REAS sit-LOC $=1 \mathrm{SG}-3 \mathrm{~N}$

('because it is my house') [el]

Just like bivalent roots, monovalent roots cannot occur independently; to form a main-clause predicate, they must be combined with another morpheme, the choice of which depends on the root. Most monovalent roots are combined either with the reflexive/reciprocal suffix -cheK or with the middle reduplication, as illustrated in (42) and (43), respectively, for the roots listed above. (Others take distributionally more restricted, unproductive suffixes with possibly specific meanings; see Haude 2006: 342-344.) Many verbs formed in this way express activities, by which the actor may or may not be seen as affected. Some middle verbs denote transitive events whose patient can optionally be expressed by an oblique noun phrase, as was shown in example (2) for the verb kaykay 'eat'.

$$
\begin{aligned}
& \text { joy-che } K \text { 'go, leave' } \\
& \text { en-che } K \text { 'stand (up)' } \\
& \text { josi:-che K'laugh' } \\
& \text { pen-che K 'land (plane, bird)' } \\
& \text { tes-cheK 'limp' } \\
& \text { de:-cheK 'lie (down)' } \\
& \text { (43) kay kay 'eat' } \\
& \text { chi: chi 'go out' } \\
& \text { Kap Kap 'bathe' } \\
& \text { ji<wa: >wa 'come' } \\
& \text { Ko<ko: > kot 'boil' } \\
& \text { de<ja: > jal 'cook' }
\end{aligned}
$$

A text example of middle verbs based on monovalent roots is given in (44). While identical with respect to morphological marking, the verb deja:jal 'cook' in (44)a denotes an activity and takes the agent (the cook) as subject, while Koko:kot 'boil' in (44)b denotes a process and takes the affected entity (the cooked food) as subject.

$$
\begin{aligned}
& \text { a. ena de<ja }>\text { jal--isne che jayna } \\
& \text { DUR.STD cook<MD >--3F.AB and DSC }
\end{aligned}
$$




$$
\begin{aligned}
& \text { che asko jayi-na }=\text { us } \\
& \text { and PRO.N.AB run-LOC }=3 \mathrm{M} . \mathrm{AB} \\
& \text { 'And that (was) where he ran to.' }
\end{aligned}
$$

While the aspectual properties of monovalent bases require further study, the data so far indicate that these bases denote activities (cf. Van Valin 2005: 55) rather than states, and in this respect differ significantly from unmarked bivalent bases.

\section{The undergoer orientation of bivalent bases}

\subsection{Orientation}

The term "orientation" is sometimes used to refer to the participant role a verb assigns to its central argument. In the transitive domain, the accusative pattern implies actor orientation and the ergative pattern undergoer orientation. In the intransitive domain, so-called unaccusative verbs are typically undergoer-oriented and unergative verbs actor-oriented.

The preceding sections have shown that in Movima, there is a split in the domain of morphologically unmarked verbal bases: the so-called bivalent bases, forming stative predicates when unmarked, are undergoer oriented; the majority of monovalent bases, in contrast, denote activities and hence can be considered actor oriented. ${ }^{5}$ A major function of the voice markers is to overtly indicate and/or modify the orientation of the voice-marked verb (see Serzisko 1991): in Movima, a verb marked as resultative (intransitive) or direct (transitive) is oriented towards the undergoer, a verb marked as agentive (intransitive) or inverse (transitive) is oriented towards the actor. Reflexive/reciprocal and middle-marked verbs, whose actor is affected by the action it instigates, have a tendency to be actor oriented; this is apparent from the effect of middle and reflexive/reciprocal marking of monovalent bases, which denote activities (see (42), (43) above). Thus, since the bivalent bases, which participate fully in the voice system, are undergoer oriented and the default transitive clause patterns ergatively, the hypothesis is that the function of the ergative marker is to permit the additional expression of the actor argument.

This hypothesis is strengthened by the fact that the resultative marker - ' $i$, which overtly marks the verb as undergoer oriented, shows signs of being closer to a zero marker than the other voice morphemes (and was analysed 
as such in Haude 2006). The correlation between resultative marking and absence of marking is both semantic and phonological.

\subsection{Semantic parallels between unmarked and resultative verbs}

When in elicitation, speakers are faced with a minimal pair of an unmarked bivalent base and a resultative form marked with - ' $i$, their explanations make it clear that the unmarked form is interpreted as denoting a state "without any implication of its origin" (Nedjalkov and Jaxontov 1988: 6), while in the resultative form, a (possibly unknown) actor is implied. Some verbs that were tested this way are listed in (49) (the parentheses in the glosses provide the interpretation of the verb with - ' $i$; bases whose stress or lengthening pattern changes when occurring with the suffix are presented independently).

$$
\begin{array}{ll}
\text { katpit(-'i) } & \text { 'be broken in halves (by someone)' } \\
\text { Kok-poj(-'i) } & \text { 'be felled (by someone)' (-poj CAUS) } \\
\text { way'choK(-'i) } & \text { 'be mended (by someone)' } \\
\text { ja:rat (jarat-'i) } & \text { 'be thrown away (by someone) } \\
\text { do'waj (dowaj-'i) } & \text { 'be moved to another place (by someone)' } \\
\text { ji:sa (ji:sa:-'i) } & \text { 'to be made (by someone)' }
\end{array}
$$

However, the distinction between simple and resultative states is not so clear-cut in natural discourse, where the forms seem to be used interchangeably.

The following examples may illustrate this. As was shown in 3.2.2, the resultative occurs in descriptions and instructions, where sequences of events are described. However, here also the unmarked forms are found, like the verb nanra in (50) (a description of raising cattle) and Kokpoj and dakato:lej in (51) (a description of how a slash-and-burn field is made): 
(50)

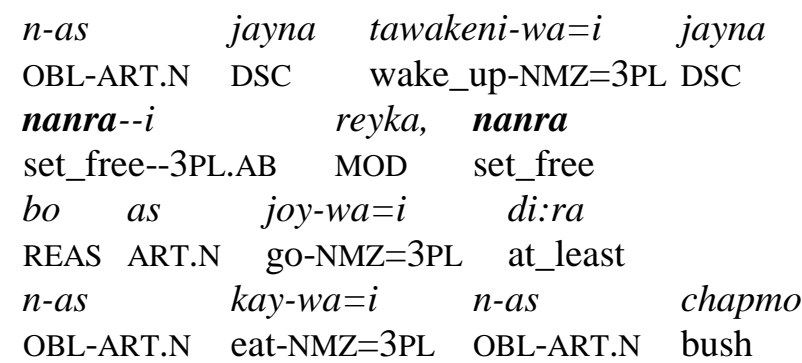

'When they [the cows] wake up, they are set free again, (they) are set free so that they go at least to feed in the bush.'

$(51)$

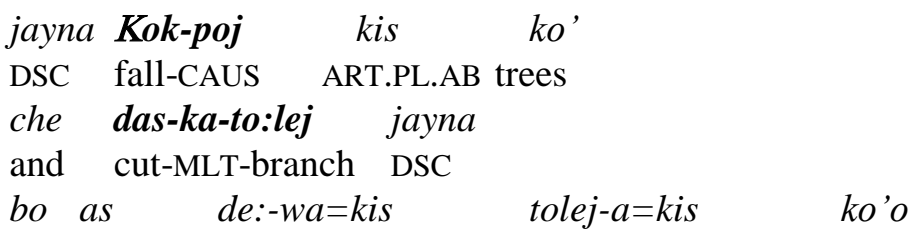
are repeatedly branch-cut), so that the branches of the trees lie flat.'

$\begin{array}{lllll}\text { kiro } & \text { kis } & \text { lotoba=is } & \text { di' } & \text { pokso, } \\ \text { DEM.PL.AB } & \text { ART.PL.AB } & \text { jug=3PL.AB } & \text { REL } & \text { chicha } \\ \text { joy-Ke } & \text { no-kos } & \text { kavildo } & & \\ \text { go-CO } & \text { OBL-ART.N.AB } & \text { Cabildo } & & \end{array}$

'There were their jugs of chicha, (they had been) taken to the Cabildo.'

On the other hand, verb roots, which cannot occur without additional phonological material, take the resultative marker - ' $i$ when denoting states that do not imply an actor, like yey' $i$ in (53) or Kek' $i$ in (54):

$$
\begin{aligned}
& \text { rim }<a:>K e=\emptyset \quad n \text {-is wa:ka-wandi buka } \\
& \text { sell }\langle\text { DR }\rangle=1 \mathrm{SG} \quad \text { OBL-ART.PL cow-INSTR:BE.house DUR.MOV } \\
& \text { bo rey yey-'i-is } \\
& \text { REAS MOD want-RES--3PL.AB } \\
& \text { 'I sold (the hats) on the ranches because they were appreciated.' }
\end{aligned}
$$




$$
\begin{aligned}
& \text { yey-na='ne os } \quad \text { ma:kina di' Kek-'i } \\
& \text { want-DR=3F ART.N.PST machine REL kick-RES } \\
& \text { 'She wanted a (sewing) machine that is foot-driven.' }
\end{aligned}
$$

The equivalence of unmarked and resultative forms is also apparent when unmarked stative verbs verbs and verbs ending in - $i$ cooccur in the same clause, as in (55) (a joke), where they denote a sequence of events:

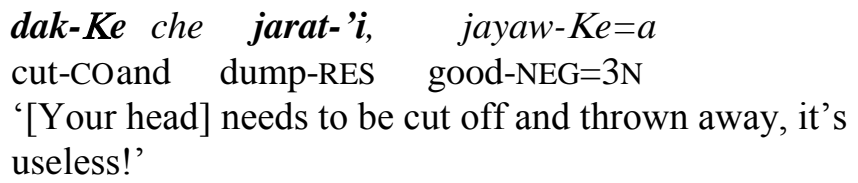

Furthermore, there are verbs where, without any obvious morphophonological reason, the attachment of - $i$ is not possible, while others cannot occur in the unmarked form. In both cases, the resultative and the stative reading are indistinguishable. For instance, the verb rimKe 'sell' in (56) cannot occur with the resultative marker, whereas the verb base rime $K$ - 'buy' in (57) cannot occur without it when denoting a state:
a. ba:ra rimKe
all sell
'It is all sold.'/ 'It has all been sold.'
b. * ba:ra rimKe-'i
all sell-RES

('It has all been sold.')

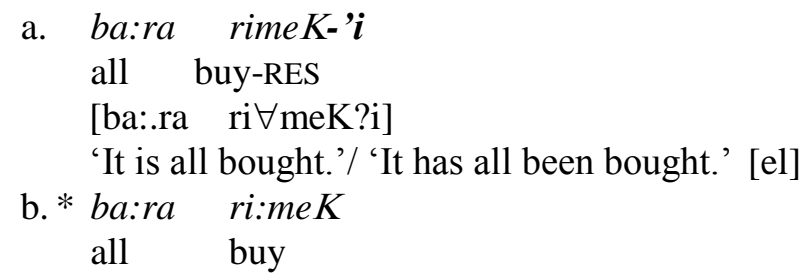

('It is all bought.') [el]

Another verb that, like $\operatorname{rimKe}$, cannot occur with the ending - ' $i$ to denote a resultative state, is jommi 'eat up' in (58): 


$$
\begin{aligned}
& \text { ban kiwa il-na=Ø bo nokowa jommi } \\
& \text { but DEM spread-DR=1SG REAS right_now eat_up } \\
& \text { 'But I have spread it there because now it will be eaten.' }
\end{aligned}
$$

Resultative verbs that, like rime $K$, cannot occur without the ending - ' $i$ (besides the monosyllabic roots) are listed in (59). For the first three verbs in this list, the most probable explanation is that they constitute verb roots and therefore cannot occur on their own; for the last two, no such explanation can be given, since they are clearly composed of a root and the causative suffix.

$$
\begin{aligned}
& \text { tikoy-' } i \text { 'be killed' } \\
& \text { e:la:- } i \text { 'be left behind' } \\
& \text { dewaj-' } i \text { 'to be seen' } \\
& \text { chi-poj-' } i \text { 'to have been taken out' ('go out'+CAUS+RES) } \\
& \text { ju:-poj-' } i \text { 'to have been punished' ('punish'+CAUS+RES) }
\end{aligned}
$$

\subsection{Phonological parallels between - $i$ and zero}

The hypothesis that of all voice markers, the resultative marker - ' $i$ comes close to zero marking receives support from the fact that the element [?i] is homophonous with a dummy element that occurs on some prosodically deficient nouns and pronouns. In Movima, a content word (noun, verb, adjective) must be minimally disyllabic. Apart from very few exceptions (Haude 2006: 196), monosyllabic noun roots are either augmented by reduplication or by attachment of the ending [?i], the choice being lexically determined. Example (60) illustrates the augmentation of the monosyllabic noun root nun- with the dummy -' $i$. The resulting form behaves like any other noun; for example, it can be marked for alienable and inalienable possession, as shown in (60)b and(60) c, respectively. Examples (61) and (62), however, where the noun forms part of a compound and an incorporating verb, respectively, show that the root of the word is nun-alone (see also Haude 2006: 207).

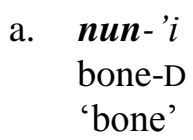

b. nun-' $i=a$

bone- $\mathrm{D}=3 \mathrm{~N}$

'its bone (al.)' c. $n u n-<{ }^{\prime} i \sim>{ }^{\prime} i=a$

bone- $<$ INAL $\sim \mathrm{D}=3 \mathrm{~N}$

'its bone (inal.)' [el] 
(61)

punta:-nun

tip-bone

'the bone from the tip (of the rib cage)'

$(62)$
it dan-a:-nun
1INTR chew-DR-bone
'I chew on bones.' [el]

The element [?i] also occurs in initial position on pronouns that do not display the required syllable structure. It augments the first-person pronominal elements $(i) K$ and $(i) t$, which consist of a simple consonant and therefore need to be attached to a preceding vowel. In (63), this vowel is provided by the preceding word; in (64), the preceding word ends in a consonant, therefore the element [?i] is inserted as a dummy host.

$$
\begin{array}{ll}
\text { jayna } t & \text { joy-cheK } \\
\text { DSC 1INTR } & \text { go-R/R }
\end{array}
$$

'Then I went.'

$$
\begin{array}{ll}
\text { ban it } & \text { joy-cheK } \\
\text { but 1INTR } & \text { go-R/R } \\
\text { 'But I went.' } &
\end{array}
$$

The personal pronouns (i) 'ne ' $3 \mathrm{~F}$ ', (i)sne ' $3 \mathrm{~F} . \mathrm{AB}$ ', (i)y' $K i$ ' $1 \mathrm{PL}$ ', and (i)y'bi '2PL', which would have a complex onset if occurring independently, are preceded by an element /i/ when occurring as free forms or when externally cliticized to a consonant-final host. Compare the variants of the thirdperson feminine pronoun $(i)$ sne '3F.AB' when cliticized to a vowel-final host, (65)a, when occurring independently, as in (65)b, and when cliticized to a consonant-final host (resyllabifying with that consonant), as in (65)c. The stress and syllable pattern is given in the phonemic representation.

$$
\begin{array}{ll}
\text { a. } & \text { salmo--sne } \\
\text { return--3F.AB } \\
\text { / } \forall \text { sal.mos.ne/ } \\
\text { 'She returned.' } \\
\text { c. isne salmo }
\end{array}
$$




\author{
3F.AB return \\ $/ \forall$ ?is.ne $\forall$ sal.mo/ \\ 'She returned.' \\ b. a:mon--isne \\ enter--3F.AB \\ $/ \forall$ ?a:.mo.\%nis.ne/
}

'She came in.'

Note that the bound pronoun in (65)c is not preceded by a glottal stop, the pronoun being resyllabified with the preceding consonant. It may be argued that here, the element /i/ cannot be compared to the sequence [?i] in the above examples. However, as was shown in Haude (2006: 101), it is a property of external cliticization that referential elements are resyllabified with the preceding consonant, and that the glottal stop, which otherwise precedes all vowel-initial morphemes, is dropped.

If - ' $i$ is a prosodically triggered element in other environments, then it is very well conceivable that also on verbal bases, it is synchronically perceived as a phonological dummy. This may be the reason why in actual speech the resultative verbs are used in the same way as unmarked bivalent verbs, given that both denote states.

\title{
6. Conclusion
}

Movima has a set of verbal voice markers that indicate the transitivity of a verb and the participant role(s) (actor, undergoer, or both) of its subject. Six voice markers can be identified, four of which mark intransitive verbs (reflexive/reciprocal, resultative, agentive, and middle) and two that mark transitive verbs (direct and inverse). Verbs unmarked for voice are intransitive, while all transitive verbs are overtly morphologically derived through direct or inverse marking. Movima can therefore be characterized as a "fundamentally intransitive language" (Nichols 1982; see also Nichols, Peterson, and Barnes 2004).

Only one class of verbal bases, termed "bivalent" because they denote two-participant events, can be productively combined with the voice markers. The other class, termed "monovalent" because most of its members denote one-participant events, only has limited access to the voice markers, and their combination with the reflexive/reciprocal or middle marker is lexically determined. In particular, monovalent bases cannot be marked as 
direct; on them, the suffixation of the element -na (the direct marker on bivalent bases) derives a locational noun.

Bivalent verbs unmarked for voice denote states. They are in this respect similar to the resultative forms, marked by the suffix - $i$. The similarity is confirmed by the distributional equivalence of unmarked and resultative forms, the fact that some can only be occur unmarked and others only marked by - ' $i$ when denoting a state, and by the fact that the suffix - $i$ is homophonous with a dummy element [?i] found in other environments. Both unmarked and resultative verbs are undergoer oriented, i.e. have a non-actor as their subject.

Direct-marked predicates are also characterized by undergoer orientation. Therefore, although both the direct and the inverse derivation are overtly morphologically marked, the direct derivation can be seen as the simpler operation, since it introduces an actor without changing the orientation of the verb. Maybe this fact has contributed historically to the basic status of the direct (ergative) construction. The inverse marker, in contrast, introduces an undergoer and at the same time changes the orientation of the verb. The inverse voice can, from this perspective, be seen as operating on the transitive level, enabling a referentially high-ranking participant to take the undergoer role.

The cross-linguistically unusual ergative bias found in Movima discourse can thus be explained by the underlying undergoer orientation of bivalent verbal bases.

\section{References}

Bickel, Balthasar

2010 "Grammatical relations typology." In The Oxford Handbook of Linguistic Typology, Jae-Jung Song (ed.). Oxford: Oxford University Press.

Comrie, Bernard

1981 “Aspect and voice: some reflections on perfect and passive." In Syntax and Semantics 14: Tense and Aspect, Philip Tedeschi and Annie Zaenen (eds.), 65-78. New York et al.: Academic Press.

Cooreman, Ann

1994 "A functional typology of antipassives." In Voice: Form and Function, Barbara A. Fox and Paul J. Hopper (eds.), 49-87. AmsterCroft, William dam/Philadelphia: Benjamins. 
2003 Typology and Universals. Cambridge: Cambridge University Press. Second edition.

DeLancey, Scott

1981 "An interpretation of split ergativity and related patterns." Language 57(3): 626-657.

Dixon, R.M.W

1994 Ergativity. Cambridge: Cambridge University Press.

Dixon, R.M.W. and Alexandra Y. Aikhenvald

2000 "Introduction." In Changing Valency. Case Studies in Transitivity. R.M.W. Dixon and Alexandra Y. Aikhenvald (eds.), 1-29. Cambridge: Cambridge University Press.

Foley, William A. and Robert D. Van Valin, Jr.

1984 Functional Syntax and Universal Grammar. Cambridge: Cambridge University Press.

Gildea, Spike

1994 Semantic and pragmatic inverse: "inverse alignment" and "inverse voice" in Carib of Surinam. In Voice and inversion, T. Givón (ed.), 187-230. Amsterdam/Philadelphia: Benjamins.

Givón, T.

1994 "The pragmatics of de-transitive voice: functional and typological aspects of inversion." In Voice and inversion, T. Givón (ed.), 3-44. Amsterdam/Philadelphia: Benjamins.

Haspelmath, Martin

1994 "Passive participles across languages." In Voice: Form and Function, Barbara Fox and Paul J. Hopper (eds.), 151-177. Amsterdam/Philadelphia: Benjamins.

Haude, Katharina

2006 A grammar of Movima. Ph. D. diss., Radboud Universiteit Nijmegen. 2009a "Reference and predication in Movima." In New Challenges in Typology 2: Transcending the Borders and Refining the Distinctions, Alexandre Arkhipov and Patience Epps (eds.), 323-342. Berlin: Mouton de Gruyter.

Haude, Katharina

Hierarchical alignment in Movima. International Journal of American Linguistics: 513-532.

Haude, Katharina

2010 "The intransitive basis of Movima clause structure." In Ergativity in Amazonia, Spike Gildea and Francesc Queixalós (eds.), 285-315. Amsterdam/Philadelphia: Benjamins.

Haude, Katharina

Forthc. "Argument encoding in Movima: the local domain." In Argument Coding Systems of Lowland Bolivian Languages (Special Issue of In- 
ternational Journal of American Linguistics), Antoine Guillaume and Françoise Rose (eds.)

Hopper, Paul and Sandra A. Thompson

1980 “Transitivity in grammar and discourse." Language 56(2):251-299.

Kazenin, Konstantin I.

2001 "The passive voice." In Language Typology and Language Universals: an International Handbook. Vol. 2., Martin Haspelmath, Ekkehard König, Wulf Oesterreicher and Wolfgang Raible (eds.), 899916. [Handbücher zur Sprach- und Kommunikationswissenschaft, 20.] Berlin/New York: Walter de Gruyter.

Keenan, Edward L. and Matthew S. Dryer. 2007. "Passive in the World's Languages." In Language Typology and Syntactic Description. Vol. 1. Clause Structure, Timothy Shopen (ed.), 325-361. Cambridge: Cambridge UP. Second Edition.

Kulikov, Leonid

2010 "Voice typology". In The Oxford Handbook of Language Typology, Jae-Jung Song (ed.), 368-398. Oxford: Oxford University Press.

Mithun, Marianne

1994 "The implications of ergativity for a Philippine voice system." In

Voice: Form and Function, Barbara Fox and Paul J. Hopper (eds.), 247-277. Amsterdam/Philadelphia: Benjamins.

Nedjalkov, Vladimir P. and Sergej Je. Jaxontov

1988 "The typology of resultative constructions." In Typology of resultative constructions, Vladimir P. Nedjalkov (ed.): 3-62. Amsterdam/Philadelphia: Benjamins.

Nichols, Johanna

1982 "Ingush Transitivization and Detransitivization." In Proceedings of the Eighth Annual Meeting of the Berkeley Linguistics Society, 445462.

Nichols, Johanna, David A. Peterson, and Jonathan Barnes

2004 "Transitivizing and detransitivizing languages." Linguistic Typology 8(2): 149-211.

Perlmutter, David M.

1978 "Impersonal passives and the Unaccusative Hypothesis.'In Proceedings of the Fourth Annual Meeting of the Berkeley Linguistic Society: 157-189. Berkeley Linguistic Society, University of California, Berkeley.

Serzisko, Fritz

1991 “Orientierung." In Partizipation, Hansjakob Seiler and Waldfried Premper (eds.), 273-308. Tübingen: Gunter Narr.

Shibatani, Masayoshi 
1985 "Passive and related constructions: a prototype approach." Language 61: 821-848.

Shibatani, Masayoshi

2006 "On the conceptual framework for voice phenomena." Linguistics 44(2): 217-269.

Siewierska, Anna

1984 The Passive. A Comparative Linguistic Analysis. London et al.: Croom Helm.

Van Valin, Robert D., Jr.

2005 Exploring the Syntax-Semantics Interface. Cambridge: Cambridge University Press.

Van Valin, Robert D., Jr. and Randy R. LaPolla

1997 Syntax. Structure, Meaning and Function. Cambridge: Cambridge University Press.

Zúñiga, Fernando

2006 Deixis and Alignment. Inverse Systems in Indigenous Languages of the Americas. Amsterdam/Philadelphia: Benjamins.

\section{Notes}

1. The data on which the study is based were collected in Santa Ana del Yacuma between 2001 and 2009, financed by the Spinoza programme Lexicon and Syntax (Radboud University Nijmegen) and by the Movima project of the DobeS programme of the Volkswagen Foundation. I am deeply greatful to the Movima speakers who shared their knowledge with me. Spike Gildea and Francesc Queixalós are thanked for their critical remarks on an earlier version of this paper, without being responsible for any shortcomings. Elicited examples are marked with [el], all other examples stem from recorded spontaneous discourse. Symbols (partly adapted from the Leipzig Glossing Rules) are: = internal cliticization; -external cliticization; <> infixation; reduplication. Abbreviations in glosses are: 1=first person; $2=$ second person; 3=third person; $\mathrm{AB}=\mathrm{absential} ; \mathrm{ABS}=$ absolute state; $\mathrm{AGT}=$ agentive; $\mathrm{APP}=$ applicative; $\mathrm{ART}=$ article; $\mathrm{BE}=$ bound nominal element; BEN=benefactive; CAUS=causative; $\quad \mathrm{CO}=$ co-participant; $\quad \mathrm{D}=$ dummy; $\quad \mathrm{DEM}=$ demonstrative; $\quad \mathrm{DET}=$ determiner; DETR=detransitivizer; DR=direct; DSC=discontinuous; DUR=durative; $E P=$ epenthetic vowel; EV=evidential; $F=$ feminine; FRUST=frustrative; INAL=inalienable; INV=inverse; HYP=hypothetical; IMM=immediate past; INSTR=instrumental; IRR=irrealis; ITN=intentional; INTR=intransitive; LOC=location; $M=$ masculine; $M D=$ middle; $M O D=$ modal; $M O V=$ moving; $\mathrm{N}=$ neuter; $\quad \mathrm{NEG}=$ negation; $\quad \mathrm{NMZ}=$ action/state $\quad$ nominalization; $\quad \mathrm{NSTD}=$ nonstanding; $\quad \mathrm{NTR}=$ neutral; $\quad \mathrm{OBL}=\mathrm{oblique}$; $\mathrm{OBV}=$ obviative marking; $\mathrm{PST}=$ past; $\mathrm{PL}=$ plural; $\mathrm{PRC}=$ process; $\mathrm{PRO}=$ free pronoun; REAS=reason; $\mathrm{REL}=$ relativizer; RES=resultative; R/R=reflexive/reciprocal; $\mathrm{SG}=$ singular; $\mathrm{TRC}=$ truncated element; $\mathrm{VBZ=verbalizer}$.

2. The terms "actor" and "undergoer" (the "macroroles" of Role and Reference Grammer; Foley and Van Valin 1984; Van Valin and LaPolla 1997; Van Valin 2005) instead of "agent" and "patient" are chosen for two reasons: firstly because a Movima clause can maximally contain two core arguments, which can represent a large range of semantic roles, includ- 


\section{Katharina Haude}

ing recipients; and secondly because the undergoer role encompasses the semantic roles patient and theme (Van Valin and LaPolla 1997: 140-141; Van Valin 2005: 52), which is relevant for the point made in the present paper, i.e., the similar orientation of stative and resultative verbs.

3. Adjectives (words like ra:pal 'red', merek 'big' and ja:yaw 'nice') are excluded from this discussion. They can participate in the voice system (e.g. jayaw-na= $\emptyset$ 'I make X nice' or jayaw-' $i$ 'be made nice' in (23)), but can be distinguished from the verbal bases in that they can be combined with the verbalizing suffixes -ni 'to be/become $X$ ' and -tik 'to make/do X', and that they can be reduplicated in subordination (see Haude 2006: 119). There are borderline cases where adjectives and stative verbs cannot be easily distinguished, and more fine-grained investigation still needs to be undertaken. However, this is not directly relevant for the present study.

4. While probably historically related, the monovalent root dejal- has to be considered as distinct from the bivalent root $d e j$-, since the ending al is unanalyzable.

5. It may be tempting to use the terms "unaccusative" and "unergative" for the "bivalent" and "monovalent" verbal bases of Movima, since these terms are syntactically based and include lexical idiosynchrasies (e.g. Movima Kokot- 'boil', which falls in one class of predominantly activity verbs like dejal- 'cook'). However, they are not very felicitous here because they rely heavily on the notions of subject (agent) and object (patient) (see Perlmutter 1978) and on syntactic tests. 